\title{
Suppression of Domestic Violence in Croatia-Quo Vadis?
}

\author{
Barbara Herceg Pakšić, Ph. D. \\ Senior assistant, Chair of Criminal sciences \\ Josip Juraj Strossmayer University, Faculty of Law \\ Ulica Stjepana Radića 13, 31000 Osijek, Croatia \\ bherceg@pravos.hr, 0912245526
}

\section{Doi:10.5901/mjss.2015.v6n6s5p410}

\section{Abstract}

Domestic violence is a specific form of violence whose suppression is a complex problem. Manifests of the state reactions are different in relation to the prevailing legislative positions on this issue. Studies indicate an increase of this negative behaviour which points out that their control is constantly gaining in importance. The purpose of this paper is to present the legislative positions on domestic violence in the Republic of Croatia. Considering the fact that it has a wide range of modalities it can be directed to different members of the family: children, parents, married and cohabiting partners, the elderly...etc. Respecting the limited scope of this paper, the underlying attitudes of criminal and misdemeanour law against domestic violence are presented. Constant changes regarding the place of this incrimination indicate indecisiveness and caution when it comes to its suppression. Each of the previously existing solution was subjected to numerous complaints from theory and practice. However, deficiencies in the implementation of legal provisions represent major obstacle, followed by the shortcomings in domestic violence victim's protection.

Keywords: domestic violence, criminal law, misdemeanour law, human rights, protection of victims.

«Family is a highly variable human group, nevertheless it is a fundamental constant of human history while other groups come and go. " (Šeparović, 1988)

\section{Introduction- Basic Determinants of Domestic Violence in Croatia}

Family can be described as a miniature society and certainly is a basis of social development. Domestic violence occurs in homes through various forms against different victims: children, parents, elders, partners... It is therefore not easy to determine its overall concept or effective control strategy. Family connection can be singled out as a cohesive factor and specific interdependence between perpetrator and the victim. In 1988 Šeparović stated that domestic violence is a part of the overall violence in very violent world and represents a harmful, widespread, relatively poorly understood and researched negative social phenomenon, with specific causes but with no easy solutions. Today, almost thirty years later, we can agree with most of his conclusion.

Significant amount of literature on the global level indicates the permanent actuality of this topic. Many studies show a steady increase of domestic violence. It is no longer just a private matter of individual. Sometimes it is called even a matter of public safety (Wolfslehner, 2014, 1). In a contemporary context, under the influence of various factors, family goes through various forms of redefinition. Some of these factors are social dynamics, woman emancipation, social development in general, the loss of family relationships...etc. We have trends of increased age of first marriage fertility rates are declining, various forms of cohabitation instead of traditional marriage are preferred, a large number of divorces is becoming usual. All leads to crisis of the family that is becoming a "crisis of the world" (Racz, 2009, 6).

Violence implies an extreme form of aggression with illegitimate use of physical or psychological force. Domestic violence is any act or omission in interaction and dynamics of mutual relations, conducted individually or collectively and directed to physical or psychological harm (Šeparović, 1988). From a psychological point of view, domestic violence can be defined as conduct aimed at control of other person by force, intimidation and manipulation. Most common forms are physical, emotional, sexual, material and labour abuse (Ajduković, 2000). According to the same author, it is the second half of the 20th century that brought an awareness of the need to prevent violence in families: in the early sixties the problem of abused children was examined, in the seventies we analyzed violence against women and in partner relationships; in the eighties highlight was on the sexual abuse of children and in the nineties on violence toward older people in the family. Some Croatian authors estimate that the latter violence is in great progression (Poredoš, Tošić, 
Lavor et al., 2005).

Many international documents are dealing with fragments of domestic violence, providing protection to certain categories of victims. Such an approach is not incorrect, but it should take into account the compliance of individual envisaged measures. Numerous studies have proved extremely harmful consequences of domestic violence. For example, violence against women is the biggest external health risk factor for women, which leads to more injuries than traffic accidents, robbery and accidents together (Pavleković, Ajduković, Mamula, 2000, 20).

Given the prevalence of domestic violence and the multiple negative effects caused, we can say that in Croatia, as well as in other countries, there is a problem of systematic access: to determine the forms of domestic violence and to lay down the sanctions in order to prevent violence and protect victims.

According to the statistic data, there is a constant growth of this kind of violence and some authors have pointed the frequency of negative interactions of this kind in the Croatian society (Hrabar, 2007). It should be noted that statistics do not provide a real picture of domestic violence, since these offenses have a large dark number. Gathering reliable data is difficult because of the complexity of the notion of domestic violence. The reasons for this conclusion can be found in poor reporting due to the fact that the victims have constant fear of a repetition of violence; evidence collecting is problematic; there is a potential social condemnation (still exists!) and "family" relationships between the offender and his victim or victims are to be considered. Possible responses to domestic violence from other countries are being monitored in Croatia. Comparative analyses were made regarding various solutions: such as the USA, Japan and Australia...etc. (see Milas, 2005). On the other hand, studies regarding status of women in society and family are not yet at systematic level.

The dynamics of abuse in the family has its own course. From a psychological point of view, it can be observed at all stages, starting from the romantic idealisation of relation until its breakup. Life experience shows that domestic violence has typically progressive line; relatively mild forms of violence are followed with harder ones, which are periodically repeating (Grozdanić, Škorić, Vinja, 2010, 691). Also, there are numerous reasons why some seek to maintain such a distorted human relationships: economic dependency, parenting, fear, saviour syndrome, duty, love, guilt, responsibility, low self-esteem...etc. The case law indicates that victims report perpetrators only after a long exposure to psychological and physical violence $($ Oset, 2014, 615). All these reasons reveal the complexity of this topic, which implies a specific approach to this problem. It can be researched from a variety of aspects, but the fact is that it is not possible to achieve control this violent behaviour without repressive state intervention. Therefore, the purpose of this paper is to present criminal law and misdemeanour law framework to suppress domestic violence in the Republic of Croatia.

\subsection{Statistic indicators of domestic violence in the Republic of Croatia, sanctions and profile of perpetrator}

According to the recent extensive research on forms and prosecution of domestic violence, data indicate increase of this violence each year. At the same time, it is considered that progress has been made in its suppressing and punishing the perpetrators (Rogić-Haždalić, Kos, 2012, 78). More specifically, in the observed four-year period 2007-2010, for a criminal offense and misdemeanour regarding domestic violence total of 62490 perpetrators were reported. Of these, 58 172 (or 93.1\%) were reported for misdemeanour and the remaining 4 318, for criminal offense. Of that number, 47965 perpetrators were convicted: 45493 perpetrators for the misdemeanour offense, and 2472 for criminal offense.

Regarding the profile of perpetrator, according to some studies of specific type of domestic violence, parents were the perpetrators of violence against children. For example, 27 years ago, in the former Yugoslavia, research was conducted on violence against children in the area of the Zagreb Municipal Court. The results showed that the incrimination of Neglecting and child abuse was committed almost exclusively by the child's parent, fathers were twice as likely than mothers (Turković, 1988). Research conducted in the area of Osijek Municipal Court, for the period 2008-2011, showed very similar results: the perpetrators of violence towards children were their fathers, married or in extramarital relationship and with secondary education (Herceg, Salitrežić, 2014).

Also, results of a study conducted at the national level showed that the perpetrator of domestic violence is mostly male (83.2\%) and between the age 40-49. The percentage of female perpetrators was $16,8 \%$. More than half of the convicted offenders were married (52.8\%), a quarter was unmarried (24.6\%), and a fifth divorced (20.4\%). When it comes to education, offenders had secondary or only primary school. Most of them are craftsman, tradesman or have no occupation. On the national level, the number of convicted offenders for domestic violence is 270.2 per 100000 inhabitants. (Rogić-Haždalić, Kos, 2012, 79-80).

Regarding the imposed sanctions, mainly suspended sentence was applied (83.1\%), followed by imprisonment (16.5\%). The perpetrators of the misdemeanour were punished by a fine $(50.8 \%)$, followed by prison $(41,8 \%)$ (Rogić- 
Haždalić, Kos, 2012, 82). It should be noted that imposition of fines is not particularly effective in the context of suppression of domestic violence. Namely, as this is a merely the obligation of the perpetrator to pay a certain amount of money to the state, there is a shortage in its inadequacy for resocialization as well as the fact that it cannot provide personal character (Novoselec, Bojanić, 2013, 404). Since the payment of fine decreases the consumer standard of entire family of the perpetrator, it represents a form of secondary victimization. Along with the punishment, it is often that courts find it justified to impose protective or security measures, of which the largest part is related to mandatory treatment of addiction.

What is particularly alarming is an established fact that in Croatia every third perpetrator of domestic violence (as criminal offense) is recidivist. For domestic violence as misdemeanour, every eighth perpetrator is recidivist. (RogićHaždalić, Kos, 2012, 80). Considering victim protection aspect, this fact is of particular concern. Also, from the standpoint of special prevention, it indicates a poor effect of sanctions on perpetrators. Special prevention (deterrence of perpetrator from future crimes), in addition to general prevention and retribution, is an integral part of Croatian provision on the purpose of punishment (Art. 41 of Criminal Code). For its achievement, it is necessary that the perpetrator perceives the imposed sanction as fair (Novoselec, Bojanić, 2013, 377). It should be noted that in the context of the perpetrators of these criminal and misdemeanour offenses it is particularly important to appropriately conduct imposed security and protective measures. It has been mentioned previously, that this measures are imposing in a high percentage which points to the fact that the courts in a number of cases find the legal requirements for imposition (risk offenders). Real problem is their quality implementation. Life experience dictates that such measures may have even a better effect on the perpetrator rather than punishment itself. A punishment is imposed retrospectively, for what has been done in the past, while these measures are prospective and are imposed with the aim that the unlawful behaviour would not be repeated pro futuro.

\section{Domestic Violence and the Violation of Guaranteed Human Rights and Freedoms}

Domestic violence violates fundamental human rights guaranteed by numerous documents at the international level. It is evident from the Vienna Declaration adopted in 1993 at UN World Conference on Human Rights, which explicite recognizes domestic violence as a human rights violation. The Republic of Croatia is a signatory to numerous international documents related to the topic concerned, but due to the limited scope of the paper, we will mention only the most important of them. The emphasis will be on the domestic legal sources that are presented in detail in the next subchapter.

When it comes to international instruments for the prevention and suppression of this kind of violence, within the framework of the United Nations, there are UN Convention on Elimination of All Forms of Discrimination against Women (CEDAW, 1979) and its Protocol from 1999, the Declaration on the Elimination of Violence against Women from 1993, the Convention on the Rights of the Child in 1989. The Rome Statute of the International Criminal Court places gender crimes and sexual violence under criminal law. Compared to the previous ad hoc statutes of international tribunals on Yugoslavia and Rwanda, the position of victims has been improved, since better conditions for compensation of damage and the possibility of involvement in the process are provided (Römkens, Letschert 2007).

Within the Council of Europe there are Recommendation R (85) 4 of 1985 on violence in the family, then Recommendation No. $\mathrm{R}(90) 2$ of 1990 on social measures for protection against domestic violence, also Recommendation Rec (2002) 5 of 2002 on the protection of women against violence. In addition, the Convention for the Protection of Human rights and Fundamental Freedoms from 1950, protects the right to life (Article 2), personal security (Article 5), family and personal life (Art. 8), prohibits torture and degrading treatment (Art. 3) and discrimination (Art. 14). Convention has its own supervisory mechanism that monitors the possible violation of its provisions in the Member states. This mechanism is the European Court of Human Rights.

This ECtHR started to deal directly with the issue of domestic violence in 2010 (Radić, Radina 2014, 729). In this context two judgments are significant for Croatia: B. Tomašić and others v. Croatia (App. no. 46598/06)1, in which a

\footnotetext{
1 The perpetrator was convicted for Threat to imprisonment of five months and a security measure of mandatory psychiatric treatment was imposed. After the expiration of a little more than a month of the time served, the offender shot his wife, daughter and himself. In considering the obligation of the state, the ECtHR, took two things as the key criteria: the predictability of events-whether the authorities knew or ought to have known of a real and immediate threat to the life and the non-application of reasonable preventive measures. Both criteria were confirmed, and the main complaint was made to the deficiencies of the national system to protect people's lives from dangerous offenders who are recognized as such by the competent authorities.
} 
violation of the right to life was confirmed and A. V. the Croatia (App. no. 55164/08)2, where a violation of the right to respect for private and family life was confirmed. In both judgments ECtHR criticized the Republic of Croatia due to its ineffective protection of victims of domestic violence and the implementation of protective measures and pointed out that the existing legislation cannot be properly implemented in practice.

One of the more recent documents is Convention on Preventing and Combating Violence against Women and Domestic Violence from 2011. Republic of Croatia became the 27th signatory state of the Convention on 22 January 2013. The purpose is to protect women from all forms of violence and to prevent, prosecute and eliminate violence against women and domestic violence, contribute to combating all forms of discrimination, to promote full equality of women and men including the empowerment of women. In order to create a comprehensive framework, protective policies and measures for assistance to all victims of violence against women and domestic violence are encouraged. It is important to promote international cooperation and provide support and assistance to organizations and competent law enforcement with the aim of effective cooperation and comprehensive approach in combating violence against women and domestic violence. The Convention was so far signed by 36 countries and ratified by 14 . Thus it is now in force, for example, in Albania, Andorra, Austria, Bosnia and Herzegovina, Montenegro, Czech Republic, Italy, Portugal, Serbia, Spain, Turkey from August 2014, and from November 2014 in France, Malta and Sweden. It has yet to be ratified in Croatia.

However, none of the mentioned documents «covers» domestic violence as a whole. In fact, one study conducted by the Council of Europe, almost 10 years ago (2006), showed that legal measures to prevent domestic violence, protect victims and prosecute perpetrators are very diverse and vary from country to country. Most countries do not have a specific legislation on combating physical domestic violence. This kind of violence mainly belongs to in the criminal law area or family-related offenses (Hagemann-White, Katenbrink, Rabe 2006). Contrary to this practice, Republic of Croatia passed a special act on combating domestic violence in 2003, as it will be discussed below.

\subsection{Types of repressive state reaction in Croatia}

There are a number of relevant acts and regulations concerning domestic violence in Croatia. Criminal Code, Act on Protection from Domestic Violence, Family Act, Criminal Procedure Code, the National Strategy for Protection against Domestic Violence for the period 2011-2016., Ordinance on the method and place of conducting psychosocial treatment, Standards for the implementation of psychosocial treatment of perpetrators of domestic violence, Protocol for handling cases of Domestic Violence and in the case of sexual violence...

The protection of marriage and the family, as well as the protection of children and young people represent the constitutional category in the Republic of Croatia. Domestic violence in possible to observe through three different aspects: criminal law, misdemeanour law and family law. In the context of effective control of this behaviour, it is necessary to have compatibility and coordination of the above mentioned branches of law. Victim protection of is achieved, inter alia, with the prescription of criminal offenses, misdemeanours and specific measures in legislation.

Legal norms which stipulate the repressive state reaction in the Croatian legal system represent a certain (positive) specificum. In fact, since the beginning of the 21st century, is clear that a response to domestic violence stands out as a separate criminal or a misdemeanour offense. This tendency is different from the other legal systems compatible with Croatian one, as these countries generally do not provide a separate incrimination for this type of violence. For example, Germany, Austria, Switzerland and France do not have separate incrimination that penalizes domestic violence (Martinović, 2011, 265, and Radić, Radina, 2014, 730-734).

The year 2003 can be marked as turning point in the Croatian legal system, since a various norms in the field relevant to this topic were adopted: Act on Ombudsman for Children, the Gender Equality Act, Act on Same-sex Communities and Family Act together with the Act on Protection from Domestic Violence. First, we will look at family law, and then misdemeanour and criminal law.

a) The family law response to domestic violence includes primarily the protection of the child in the context of imposition of certain measures to parents. Family Act (Official Gazette 162/98) was the first act that sanctioned domestic violence. It was in a form of misdemeanour, through Art. 118. It entered into force on 1 July 1999 and provision content was as follows: "A violent behaviour from a spouse or any other adult

\footnotetext{
2 Several misdemeanour and criminal proceedings were started against perpetrator for different forms of domestic violence, but in the period of five years, no verdict was pronounced and none of the imposed measures was carried out. The ECtHR found that the national courts, pronouncing variety of measures (detention, psychosocial treatment, protective measures and safety regulations, of mandatory psychiatric treatment) demonstrated their necessity, but ultimately these measures had not been implemented.
} 
member of the family is prohibited." A provided sanction was deprivation of liberty for up to 30 days. Many of complaints were directed to this solution, coming both from the «theory» (Milas, 2005, 983-984) and from practice (summary of complaints, Oset, 2014, 588). Regardless of that, this opened the way to more appropriate state response.

In 2003, a new Family Act was adopted. (It is yet valid with numerous amendments, Official Gazette 116/2003, 17/2004, 136/2004, 107/2007, 57/2011, 61/2011, 25/2013, 75/2014, 5/2015). It no longer penalized this behaviour as an offense, but focused on the protection of the child from the violent behaviour of family members. The reason was the fact that misdemeanour responsibility was provided through the Act on Protection from Domestic Violence. The toughest possible family law measure is deprivation of parental care. The parent who abuses or grossly violates parental rights and duties can be deprived from parental care in non-litigation proceedings. However, although the commission of offenses against a child is a self-evident example of gross violation of parental responsibility, one study conducted has shown that this measure in practice is not imposed as it should be, regardless of the existence of legal preconditions (Herceg, Salitrežic 2014). When domestic violence against children is committed by other members of the family, it is possible to impose some measures: committal to an institution for social care if the perpetrators are siblings. If the perpetrators are grandparents, the measure of restraining harassment of the child can be imposed. It is certainly necessary to initiate misdemeanour or criminal proceedings.

b) Misdemeanour sanctioning of domestic violence is the result of efforts to accelerate the state reaction and to be more effective. Therefore, the Act on Protection from Domestic Violence was passed initially in 2003. In 2009 a new one was adopted (Official Gazette 137/2009, 14/2010, 60/2010), with clearer defined modalities of violence. According to this Act (Art. 3) family consists of women and men married or in extramarital community, common children and children of each of them; blood relatives in a direct line without limitation, in the collateral line to the third degree, by marriage to the second degree; people who have children together; guardian and the ward, foster parent and member of the foster family and members of their families while the relationship lasts. Violence (Art. 4) implies any form of physical, psychological, sexual or economic violence, including, for example, and corporal punishment of children in the educational purposes, sexual harassment, physical coercion, destruction/damage to common property..etc. As an example of economic violence one can mention a situation when one spouse takes advantage of the absence of another, due to hospitalization, and vacates the apartment of the common things, solds common personal vehicle and disputes the existence of joint property while marriage still formally lasts (Oset, 2014, 594).

Specific obligation is provided: health care workers, professional staff of social welfare, professional staff of family prevention and protection, education, labour, religious institutions, humanitarian organizations and society organizations have to report the information on committing domestic violence for which they learned in the context of its competence. Although this obligation is set out in good faith, the practice shows that it is not easy to implement it. For example, in health care there are no adequate records of victims of domestic violence.

The stipulated sanctions are protective measures (mandatory psychosocial treatment, restraining order, prohibition of harassment or stalking, removal from the family home, mandatory treatment of addiction and seizure), imprisonment (up to 90 days) and fine (minimum of 1000 HRK, while for repeat domestic violence minimum of 15000 ).

With regard to the current expression of the Act, it should be noted that there is insufficient determination of kinship/congenial relation in certain cases. Specifically, when regulating the sanctioning of repeated commission of violence in the presence of a child (Art.20 of this Act, in para. 4 and 6: a minor or a person with disability), there is no prominent family characteristic. Although according to «letter of the Act» it can be a case of no relatives or family connections (which undoubtedly creates practical difficulties in procedure since the notion can go too broad), given the teleological interpretation of the legislator intention, ceterum censeo it should be taken as a child, minor or a person with disabilities, who is a member of the perpetrator family. The notion "family member" is sometimes not even determined in practice of misdemeanour courts when a person is convicted (High Misdemeanour Court, JŽ-2999/2012).

c) Criminal offense regarding domestic violence has been introduced in 2000, with the Amendments to the Criminal Code (Official Gazette 129/00). Art. 215a called Violent conduct within a family was added. Before its introduction as a separate offense, domestic violence could have been prosecuted through other incriminations: bodily harm, grievous bodily harm, sexual misconduct, defamation and others, depending on the circumstances and in concreto. The provision was as follows: "The family member who uses violence, 
harassment or particularly insolent conduct and places another member of the family into a humiliating position shall be punished by imprisonment of six months to five years." The incrimination had significant deficiencies. The very text of incrimination makes it evident that this is a delictum proprium, but comparing the parallel positive norms of the Act on Protection from Domestic Violence (Art. 3, furthermore APDV) and previous Criminal Code ( Official Gazette 110/1997, 27/1998, 50/2000, 129/2000, 84/2005, 51/2001, 111/2003, 190/2003, 105/2004, 71/2006,110/2007, 152/2008, 57/2011,77/2011, furthermore CC/97) (Art. 89 para. 30), one comes to the conclusion that the APDM sets the notion «family» more broadly. Specifically, CC/97 did not mention specific categories such as custodian and guardianship, foster parent and the person placed in a foster family and the members of their families. Furthermore, complaints have been addressed to the set of actions of commission, whose basic terms have not been defined in the CC/97. So the major opinion at the time was that it is too extensive.

It was defined as "violence, abuse or particularly impertinent behaviour". In this regard, the violence implied physical or psychological force, sexual or economic violence or violence against things (Turković in Novoselec et al., 2011, 212). According to the same author, abuse had the same meaning and according to other authors, it was a behaviour that had weaker intensity than violence (Pavišic et al, 2007, 535). Particularly insolent conduct included insults, arrogance, a behaviour that deviates considerably from the usual (Turković in Novoselec et al ., 2011, 212). It is evident, that there was a coincidence and overlapping of certain forms of violence in the broad sense.

It is enough just to point out that judges have had a problem in the interpretation of these forms. For example, behaviour of son, shouting at the mother not to interfere in his affairs and to go out of the house or he is going to hit her, was not considered violent family behaviour. Court found that this kind of behaviour does not represent a particularly insolent conduct (County Court Bjelovar, Kž-437/08), even though the meaning of this behaviour was, inter alia, behaviour that deviates substantially from usual. Objective requirement was bringing in humiliating position. Modelled by the Swedish criminal provision (Law 1999: 845, Chapter 4, Section 4a), this was interpreted as a "gross violation of integrity" with the loss of self-esteem and self-confidence. It was thought that this objective condition does not have to be included in the perpetrator's intent, but the judgments showed that sometimes that was required (in detail, Martinović, 2011, 269-271).

Regarding the imposed sanctions for offenses committed under the Art. 215a, typically pronounced sanction was suspended sentence with supervision. In a number of cases special obligations were imposed, such as mandatory treatment of addiction, the obligation of psychosocial treatment and others (Brkić, Loje, 2014, 100). Many complaints were referred to this incrimination: interweaving with numerous other incriminations without a clear demarcation criteria (Herceg, Salitrežić, 2014, 75), questions of concurrence, the absence of borders between this crime and misdemeanour offense form APDV with no clear criteria for procedure... Some practitioners believe that this border is often not determinable (Oset, 2014, 589). The latter remark became especially important after the judgment of the ECtHR in the case Maresti v. Croatia (judgment of 23.07.2009., Application no. 55759/07): the violation of the of ne bis in idem principle (Art. 4 Protocol 7 to ECHR) was confirmed, which incurred by conducting misdemeanour and criminal proceedings for the same offense.

This, in Croatian literature often analyzed judgment, started the way of a clearer demarcation of misdemeanour from criminal offenses. It was therefore rightly highlighted that the provision of this incrimination was too wide, unclear and contrary to the requirements of the principle of certainty (lex certa) as part of the principle of legality (Turković in Novoselec et al., 2011, 213; Martinović, 2011, 277).

Because of all this, the group working on the new Criminal Code (further: $\mathrm{CC}$ ), decided to delete this incrimination. This attitude was ultimately accepted. This means that this CC (Official Gazette 125/11, 144/12), which entered into force on 1 January 2013, no longer anticipated domestic violence as a form of criminal offense. After twelve years of its existence, the sanctioning was left completely to the field of misdemeanour law. However, that there was no absolute decriminalization of domestic violence. It was anticipated that future domestic violence behaviour will be processed through the following criminal offenses: bodily injury, serious bodily injury, aggravated bodily injury, coercion, threat, insult, serious crimes against sexual freedom, serious crimes of sexual abuse and exploitation of children. The circumstance that the perpetrator committed violence against members of his family was a qualifying circumstance in a variety of criminal offenses, since the family members were included in a close person concept.

This led to a specific prosecution. For example, an offender who has his wife beat up all over the body, cut her with a knife on hand, threatened to kill her holding the knife at her heart, and then under her neck, committed two criminal offenses: Bodily injury under Art. 117. para. 2, and Threat, Art. 139. para. 2 CC (Virovitica 
Municipal Court, K-3 / 13-24). Various complaints were directed to this incrimination solution: domestic violence ceases to be "visible" and makes it difficult to track statistics (that will have to go through an analysis of other crimes, such as injury); reduction in social significance of domestic violence, lack of protection of victims, requirement that severe domestic violence modalities need criminal protection (Moslavac, 2013), faster possibility of recidivism ... etc.

Although response through misdemeanour procedure is generally faster than the criminal one, the effectiveness of providing protection to victims is questionable considering that the envisaged misdemeanour sanctions were less severe. Some practitioners pointed out that the new Criminal Procedure Act insists on the cost benefit principle and effective treatment, reducing time limits for taking action. Therefore, it is achievable that the perpetrator can be punished in the short time period. Additionally, in order to speed up, a specific withdrawal of withholding testimony from privileged witnesses was proposed (Moslavac, 2013). It can be said that this concept of responsibility for domestic violence was subjected to criticism since the beginning. This was particularly obvious in violent brutal behaviours that did not end with injury or other criminal offense and therefore were prosecuted merely as misdemeanour offense.

As a response to these critics, a new criminal offense was proposed. It was meant to be called "Psychological violence in the family", with content as follows: "Who with prolonged serious insulting or intimidation of a close person severely impairs her psychological integrity". This proposal was subjected to criticism immediately: the concept of favourizing only psychological violence against individuals was unclear; it would lead to uneven protection of victims; the notion of psychological integrity in itself is vague ... etc. So this proposal reached only to first reading in the Croatian Parliament, afterwards professional debates were held that have shown the insufficiency of this incrimination for all forms of domestic violence that deserve criminal responsibility.

What followed next was a change of attitude of the legislator. The Act on Amendments to the Criminal Code (Official Gazette 56/15), entered into force on 30 May 2015, adding a new Article 179a, entitled "Domestic Violence". Thus, after two and a half years (01 January 2013 -29 May 2015) domestic violence was recriminalized in $\mathrm{CC}$. The Article states that "The one who has seriously violated the regulations on protection from domestic violence and thus to a family member or to close person caused fear for safety or the safety of persons close to this person or brings person into a humiliating position, and by this act a graver criminal offense is not committed, shall be imprisoned up to three years. "This is an individual criminal offense related to the manifests of violence that have not resulted in some other offense. The intensity of the violence shows that misdemeanour liability is not sufficient.

For example, heavy insults, intimidation, physical, sexual abuse, etc. (The final proposal on amendments to the Criminal Code). This is a specific offense, suggesting violation of other regulations concerning protection from domestic violence. Regarding prosecution, higher criminal quantity is required, derived from two cumulative conditions: a grave breach of subject regulations and serious consequences (fear for safety). Thus formed criminal offense gives a clearer demarcation from the misdemeanour offense. Maintaining the concept of qualified criminal offenses when they are committed against a person close to, a subsidiary of this new criminal offense of domestic violence is proposed: domestic violence will be a solution if "another (harder) a criminal offense" is not committed.

Two more acts should be mentioned that are adopted to combat domestic violence at national level.

First one is the Protocol for handling cases of domestic violence that aims to provide conditions for effective and comprehensive reaction of the competent authorities, in order to improve protection and assistance to victims of domestic violence as well as to help the offenders to change their behaviour and value system in order to enable non-violent conflict resolution. The competent authorities in terms of the protocol are police, social care centres, health care and educational institutions and judicial bodies. Second document is National Strategy for Protection from Domestic Violence (Official Gazette 20/11). As the basic goals this Strategy emphasizes prevention of this type of violence, improvement of interdepartmental cooperation, training of professionals working in the field of domestic violence, psychosocial treatment of offenders, improvement of the legislative framework, care and support to victims of domestic violence as well as raising public awareness of the issues.

d) Specific procedural questions regarding domestic violence: Collecting evidence in domestic violence cases represents a delicate difficulty. It involves interference in highly personal relations between family members. Although victims seek protection of state authorities proprio motu and report the perpetrator, it should be noted that withdrawals or changes in their testimonies happened often. This was greatly complicating sanctioning of perpetrators in conreto. These testimonies are often crucial in criminal proceedings 
of domestic violence. The possibility of withdrawal represented "significant problem for the prosecution that directly affected the quality and efficiency of the procedure" (Moslavac, 2014, 4).

Victims, according to a previous regulation, enjoyed the privilege of not testifying, while later this privilege was modified. The amendments to the Criminal Procedure Act changed the Art. 285. Changes came into force on 15 December 2013. Article regulates exemption from testifying in criminal proceedings for certain categories of people, including, in the context of the subject of this paper, the person with whom the accused person is married or in extramarital union, relatives in the direct line, relatives in the collateral line to the third degree and relatives by marriage to the second degree, an adoptee and the adoptive parent of the accused.

Standing in the aforementioned legal relation with perpetrator, these persons do not have to testify in criminal proceedings. The competent authority has to inform them on this right. However, if they do decide to testify, the competent authority has to inform them that their statement, regardless of any future change of mind, can be used as evidence. This prevents domestic violence victims from withdrawal of their statements in later stages of the proceedings but also makes it easier for prosecution to prove violence in concreto. There are no specialized courts that would deal with cases of domestic violence in Croatia. For example, Canada has introduced Domestic violence courts in 1991; first one was in Winnipeg, Manitoba. The purpose was to respond to family violence more effectively (Beaupré, 2015, 9). It is stated that they cooperate with other sectors of community such as treatment agencies, specialized police units, victim advocates and probation officers. It seems that, given the high rate of domestic violence and recidivist level, it would be appropriate to rethink even more active state response in this direction. It would increase the importance of justice system role in combating domestic violence.

\section{Conclusion}

Frequent changes in legislative positions regarding domestic violence are sending a message of state reaction uncertainty and indecisive mechanisms of suppression. In the last fifteen years Republic of Croatia has had different versions of domestic violence suppression strategy. First, regulation in misdemeanour sphere exclusively, second through simultaneous offenses in misdemeanour and criminal law. In this context, situation was followed by procedural implications regarding the existence of dual incrimination. Enforcement of criminal and misdemeanour procedure involves a breach of guaranteed non bis in idem principle. Selection of one procedure had not been transparent due to interlocking similar modalities of violence that could be subjected to criminal and misdemeanour procedure as well.

Third solution was to delete the penal incrimination and surrender the suppression to misdemeanour law. Fourth and positive situation (again) implies both misdemeanour and criminal involvement in family relations. Recent modifications have brought improvement in demarcation, since a grave breach of subject regulations is required as well as realization of severe consequences. While this reluctance in legislation attitudes is not reassuring when it comes to the state response to perpetrators of domestic violence, some authors have recently expressed their approval regarding domestic violence «come back» in criminal law, believing that this synergy solution is a proper way of better suppression results to be achieved.

Studies have shown that children exposed to domestic violence adopt and implement it as a way of "communication" with each other in adulthood, whereby such behaviour is not manifested only in the family but also in the wider environment. That's reason enough why we should constantly be putting efforts in suppressing this unlawful and highly damaging behaviour. It is necessary to pay special attention to the following elements: capable and educated human resources sensitized to the problem of domestic violence; activity coordination of relevant state authorities since obvious reaction incoherence that leads to lack of quality protection for victims was confirmed; simplified procedures and reinforced mechanisms of restraining orders for perpetrators. It would be justified to think about more active role of justice system through specialized courts for domestic violence in the future.

\section{References}

Ajduković, M. (2000), Određenje i oblici nasilja u obitelji [Definition and forms of family violence] in M. Aduković, G. Pavleković, (Eds.) Nasilje nad ženom u obitelji, Društvo za psihološku pomoć, Zagreb, 11-15.

Ajduković, M., Mamula, M. (2000), Dinamika zlostavljanja unutar obitelji [The dynamics of abuse within the family ] in M. Aduković, G. Pavleković, (Eds.) Nasilje nad ženom u obitelji, Društvo za psihološku pomoć, Zagreb, 81-87.

Beaupré,P. (2015), Cases in adult criminal courts involving intimate partner violence, Canadian Centre for Justice Statistic, Juristat, Statistic Canada Catalogue no. 85-002-X, 3-28.

Brkić, G., Loje, G. (2014), Sankcioniranje obiteljskog nasilja [Sanctioning of domestic violence] Pravo i porezi, 7-8/14, 91-100. 
Grozdanić, V., Škorić, M., Vinja, I. (2010): Nasilje u obitelji u svjetlu promjena Kaznenog zakona [ Domestic Violence in the scope of changes to the Criminal Code], Hrvatski ljetopis za kazneno pravo i praksu, vol.17, n. 2/2010.

Hagemann-White, C., Katenbrink, J. Rabe, H. (2006), Combating violence against women Stocktaking study on the measures and actions taken in Council of Europe member States, Directorate General of Human Rights Strassbourg, <http://www.coe.int/t/dghl/standardsetting/equality/03themes/violence-against-women/CDEG(2006)3_en.pdf> , 15 June 2015.

Herceg, B., Salitrežić, A. (2014), Odnos između kaznenih djela na štetu djeteta i poduzimanja mjere lišenja roditeljske skrbi [The relation between criminal offenses against children and measure of deprivation of parental care] in B. Rešetar, S. Aras (Eds) Represivne mjere za zaštitu osobnih prava i dobrobiti djeteta, University of Josip Jurja Strossmayer, Faculty of Law, Osijek, 67-82.

Hrabar, D. (2007), Nasilje u obitelji [Domestic Violence] in M. Alinčić, D. Hrabar, D. Jakovac-Lozić, A. Korać Graovac, Obiteljsko pravo, Narodne novine, Zagreb, 255-257.

Kazneni zakon [ Criminal Code] Official Gazette 110/97, 27/98, 50/00, 129/00, 51/01, 111/03, 190/03, 105/04, 84/05, 71/06, 110/07, 152/08, $57 / 11$.

Konačni prijedlog o izmjenama i dopunama Kaznenog zakona [The final proposal of amendments to the Criminal Code], <https://vlada.gov.hr/UserDocsImages//Sjednice/2015/221\%20sjednica\%20Vlade//221\%20-\%201.pdf>, 01 June 2015.

Konvencija o sprečavanju i borbi protiv nasilja nad ženama i nasilja u obitelji iz 2011 [Convention on preventing and combating violence against women and domestic violence] <http://www.ured-ravnopravnost.hr/site/images/pdf/prijelom_online konvencija.pdf> 17 June 2015.

Martinović, I. (2011), Kaznenopravni aspekti obiteljskog nasilja [Criminal law aspects of domestic violence] in I. Radačić, J. Vince Pallua, J. (Eds): Ljudska prava žena, razvoj na međunarodnoj i nacionalnoj razini 30 godina nakon usvajanja Konvencije UN-a o uklanjanju svih oblika diskriminacije žena, Institut za društvene znanosti Ivo Pilar, Zagreb. 261-280.

Milas, I. (2005), Nasilje u obitelji-pravni aspekti [Domestic violence- legal aspects], Zbornik Pravnog fakulteta u Zagrebu, Vol.55, n.3-4, 961-999.

Moslavac, B (2014), Psihičko nasilje u obitelji kao zasebno kazneno djelo [Psychological violence in the family as a specific criminal offense] IUS Info, <http://www.iusinfo.hr/Article/Content.aspx?SOPI=CLN20V01D2014B747>, 25 June 2015.

Moslavac, B. (2013), Upitnost kaznene dekriminalizacije nasilničkog ponašanja u obitelji [The questionable decriminalization of domestic violence in Criminal law], Hrvatska pravna revija, 7-8/2013.

Novoselec, P., Bojanić, I., Cvitanović, L., Derenčinović, D., Grozdanić, V., Kurtović, A., Turković, K. (2011): Posebni dio kaznenog prava [ Special Part of Criminal law], second edition, Sveučilište u Zagrebu, Pravni fakultet.

Novoselec, P., Bojanić, I. (2013), Opći dio kaznenog prava [General Part of Criminal law], Sveučilište u Zagrebu, Pravni fakultet, .

Oset. S. (2014), Prekršajnopravna zaštita od nasilja u obitelji, [ Protection against Domestic Violence provided by Misdemeanour law], Hrvatski ljetopis za kazneno pravo i praksu, vol.21, n. 2/2014, 579-618.

Pavišić, B., Veić, P., Grozdanić, V. (2007), Komentar Kaznenog zakona [Comentary of the Criminal Code], Narodne novine, Zagreb.

Pavleković, G., Ajduković, M., Mamula, M. (2000), Nasilje nad ženom u obitelji:osobni, obiteljski ili javnozdravstveni problem? [The violence against women in the family: personal, family or public health problem?] in M. Aduković, G. Pavleković, (eds) Nasilje nad ženom u obitelji, Društvo za psihološku pomoć, Zagreb, 17-28.

Poredoš, D., Tošić, G., Lavor, T., Jerković, S., Tomurad, M., Grgić, Z. (2005) Osobe starije životne dobi žrtve nasilja u obitelji [Elderly victims of domestic violence], Policija i sigurnost, 14, n.1-6., 36-48.

Protokol o postupanju u slučaju nasilja $u$ obitelji [Protocol for handling cases of domestic violence] , <http://www.iusinfo.hr/Appendix/DDOKU HR/DDHR20140128N8924 1.pdf>, 17 June 2015.

Racz, A. (2009), Uvjerenja medicinskih sestara o nasilju nad ženom u obitelji i spremnost na suradnju sa službom socijalne skrbi [Beliefs of nurses about violence against woman in the family and willingness to cooperate with the ministry of social welfare], Pravni fakultet, Studijski Centar socijalnog rada, Sveučilište u Zagrebu, doctoral dissertation.

Radić, I., Radina, A. (2014) Zaštita od nasilja u obitelji: obiteljskopravni, prekršajnopravni i kaznenopravni aspekt [ Protection against violence in home [Domestic Violence-Family law, Misdemeanor and Criminal aspects], Zbornik radova Pravnog fakulteta u Splitu, 51, n. 3/2014.

Rogić-Haždalić, D., Kos, J. (2012), Nasilje u obitelii: pravni okvir i pojavni oblici 2007-2010 [Domestic Violence: Legal Framework and Forms of Appearance, 2007-2010], Državni zavod za statistiku, Zagreb.

Römkens, R., Letschert, R. (2007), Studija provedivosti konvencije o suzbijanju obiteljskog nasilja [Study

on enforceability of the Convention against domestic violence] < www.uvt.nl/intervict> 25 May 2015.

Šeparović, Z. (1988), Nasilje u obitelji, pojave-uzroci-rješenja [Domestic violence: Incidence, causes, solutions] in Z. Šeparović (Ur.) Nasilje u obitelji, Jugoslavensko viktimološko društvo, Dubrovnik, 3-15.

Turković, K. (1988), Nasilje nad djecom; istraživanje krivičnog djela zapuštanja i zlostavljanja maloljetnika u praksi općinskog suda u Zagrebu [Violence in the Family-maltreating and neglecting minors, some results of the research undertaken on the County Court of Zagreb] $u$ Z. Šeparović (Ur.) Nasilje u obitelji, Jugoslavensko viktimološko društvo, Dubrovnik, 85-97.

Turković, K., Novoselec, P., Grozdanić, V., Kurtović Mišić A., Derenčinović, D., Bojanić, I., Munivrana Vajda, M., Mrčela, M., Nola, S., Roksandić Vidlička, S., Tripalo, D., Maršavelski, A. (2013) Komentar Kaznenog zakona [ Commentary of the Criminal Code], Narodne novine, Zagreb.

Vienna declaration adopted by the World Conference on Human Rights on 25 June 1993 , <http://www.ohchr.org/EN/Professionallnterest/Pages/Vienna.aspx> 20 May 2015.

Wolfslehner, B. (2014), Schutz vor Gewalt in der Familie. Maßnahmen gegen physische und psychische Beeinträchtigungen im Straf-, Zivil- und Verwaltungsrecht, Dissertation, Universität Wien.

Zakon o kaznenom postupku [ Criminal Procedure Code] , Official Gazette 152/2008, 76/2009, 80/2011, 91/2012, 143/2012, 56/2013, 145/2013, 152/2014.

Zakon o zaštiti od nasilja u obitelji [The Protection from Domestic Violence Act ] , Official Gazette, 137/2009, 14/2010, 60/2010 